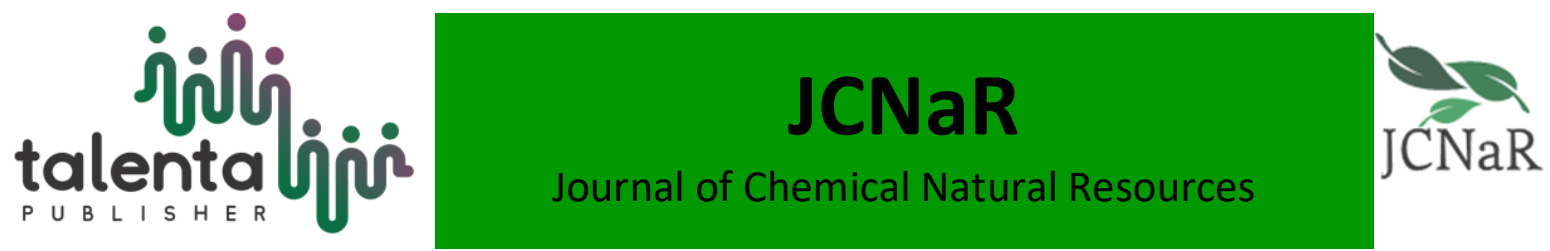

\title{
Biosorption of $\mathrm{Zn}$ (II) Metal Ion by Ca-Alginate Immobilized Durian (Durio Zibethinus) Seed
}

\author{
Intan Lestari', Desy Kurniawati2, Rahmiana Zein ${ }^{3}$, Hermansyah Aziz ${ }^{4}$ \\ ${ }^{1}$ Department of Chemistry Faculty of Science and Technology Universitas Jambi, \\ Jambi 36361 Indonesia \\ ${ }^{2}$ Laboratory of Environmental Analytical Chemistry, Universitas Negri Padang, Indonesia \\ ${ }^{3,4}$ Laboratory of Environmental Analytical Chemistry, Universitas Andalas Indonesia
}

\begin{abstract}
Heavy metal biosorption by alginate immobilized durian seed has been done. The immobilization of durian seed powder to Ca-alginate was able to improve biomass adsorption process, increase uptake capacity, ease separation from solution, generate and repeat biosorbent. In this experiment the effect of $\mathrm{pH}$, contact time, concentration and temperature on the uptake capacity of metal ions $\mathrm{Zn}$ (II) in solution were studied. Biosorption was done batch methods and result was studied Langmuir and Freundlich adsorption isotherm. The adsorption of heavy metal was optimum in $\mathrm{pH} 5$ with 75 mins contact time and $\mathrm{Zn}$ (II) ion under the concentration of $250-300 \mathrm{mg} / \mathrm{l}$. The adsorption isotherm data was characterized using Langmuir and Freundlich equation. The equilibrium biosorption isotherm showed that alginate immobilized durian seed process has high affinities with adsorption capacities of $25.05 \mathrm{mg} / \mathrm{g}$. All results showed that alginate immobilized durian seed is an alternative low cost biosorbent for heavy metal ion removal from aqueous solution.
\end{abstract}

Keyword: Biosorption, Durian seed (Durio zibethinus), heavy metal, immobilized

Received 30 July 2019 | Revised 26 August 2019| Accepted 29 August 2019

\section{Introduction}

Heavy metal contamination in waters is increasing with waste disposal to water-bodies (Sari A, 2009). This issue is being paid big attention to because heavy metals are nondegradable in the environment and dangerous for the species in the water. They are able to bring toxic effect to human, animals and plants in the environment, even at a very low concentration (Das et al, 2007). Heavy metals are accumulated in the food chain and affecting human health.

Various of chemical and physical methods have been used to remove heavy metal ions from solutions in the past few decades. These methods involved filtration, precipitation, solvent extraction, coagulation, ion exchange, evaporation, reverse osmosis, electrolysis and membrane process (Sari A, 2009; Abbas et al, 2014; Tijani et al, 2013). However, the application of those

\footnotetext{
*Corresponding author at: Department of Chemistry Faculty of Science and Technology Universitas Jambi, Jambi and Indonesia

E-mail address: ilestari_15@unja.ac.id
} 
processes are often limited by technique and cost factors. Ion exchange and adsorption, for instance are very effective. However they required expensive adsorbent materials and complicated processes (Das et al., 2001). Nevertheless, ion exchange and adsorption, also solvent extraction, are the most commonly used among those methods mentioned.

New study to remove heavy metals from waste directs to biosorption technique which is based on metal bonds in biological materials. Biosorption is a relatively new process that has shown a signifi- cant contribution for the removal of contaminants from aqueous effluents. Biosorption can be defined as the removal of metal or metalloid species, compounds and particulates from solution by biological materials or a by-product or waste material from another industry (Coelho, Laus, Mangrich, de Favere, \& Laranjeira, 2007; Gadd, 1993). Biosorption process is fast and the reaction can be reversible from the metals bind with biomass. Biosorption mechanism shows that lignocellulose has absorption ability and generally acts as adsorbent with its structure and polymer compounds (Osman, 2010, Pehlivan et al, 2012 )

Immobilized biomass is the stage needed to scale up biosorption in industrial scale. Durian seed biomass in powder (native) form is less preferred as it cannot stand in acidic solution that leads to difficulties during the separation after biosorption process. The advantages of biomass immobilized in alginate are to improve biomass performance in dynamic absorption, increase absorption capacity and ease biomass separation from the solution. (Kacar, Y., et. al, 2001 ) Biosorbents are able to be regenerated without damaging the structures of biomass and can be used for repetitively (regenerate) (Aksu et al, 1998).

This study aims to immobilize durian seed powder to Ca-alginate polymer matrix in bead forms in order to be used as a relatively strong mechanical biosorbent which is able to stand in aqueous solution media. Moreover, the study is to determine the maximum absorption capacity of $\mathrm{Zn}(\mathrm{II})$ ion.

\section{Materials and Methods}

\subsection{Tools and Materials}

Field Emission-Scanning Electron Microscope (FE-SEM) (Inspect F-50 FEI Company USA), Atomic Absorption Spectrophotometry (AAS WFX -320 Ray light, Braigh China, FTIR (FT/IR460 Plus, Jasco Japan), analytical balance, durian seed from durian sellers in Padang. Biosorption experiment was done by stock standard solution (1000 mg/L) from Zn(NO3) Merck (Germany), Na-alginate, $\mathrm{CaCl} 2, \mathrm{HNO} 3$ and $\mathrm{NaOH}$ and aquadest. $\mathrm{Zn}(\mathrm{II})$ standard solution was made fresh from the mother liquor. 


\subsection{Durian Seed Preparation and Characterization}

Durian seed preparation is referred to the previous research (Lestari et al 2016). The dried durian seed powder was immobilized to Ca-alginate as the procedure in Mahamadi and Zambara (2010).

Polymer alginate $2 \%$ solution was made by solving $2 \mathrm{~g}$ alginate into $100 \mathrm{~mL}$ deionized solution and followed by agitation for $4-6$ hours using magnetic stirrer at $100 \mathrm{rpm}$. To make homogenized polymer solution, $2 \mathrm{~g}$ durian seed powder biomass was mixed into $100 \mathrm{~mL}$ of $2 \%$ alginate. Next, the mixture was formed into beads by dripping the mixture to $\mathrm{CaCl} 20.1 \mathrm{M}$ solution by gravimetry with a syringe. Beads formed were hardened in $\mathrm{CaCl} 22 \%$ solution for 24 hours and washed with distilled water while stirred at $100 \mathrm{rpm}$ for 30 minutes. It is repeated for $3-5$ times until neutral $\mathrm{pH}$ was reached. The bead was dried at room temperature and stored at a sealed container.

\subsection{Biosorption Experiment}

Biosorption experiment was done by mixing $0.1 \mathrm{~g}$ durian seed powder biosorbent or $\mathrm{Ca}-$ alginate immobilized durian seed beads with $20 \mathrm{~mL} \mathrm{Zn}$ (II) $10 \mathrm{mgL}-1$ solution. The mixture was shaken for 60 minutes at $150 \mathrm{rpm}$ and filtered. The concentration of $\mathrm{Pb}$ (II) ion in the solution was analyzed by Atomic Absorption Spectrophotometry AAS (spectra 20 variant) . The optimum conditions learned are effect of $\mathrm{pH}$, contact time, $\mathrm{Zn}$ (II) concentration and temperature. The total of metal ion absorbed per gram biomass for biosorption capacity can be calculated by the equation below:

$\mathrm{Qe}=\frac{\mathrm{Co}-\mathrm{Ce} \cdot \mathrm{V}}{\mathrm{M}}$

Where $\mathrm{Co}$ and $\mathrm{Ce}$ are the initial concentration of metal ions in the solutions and equilibrium (mgL-1) respectively, $\mathrm{V}$ is the volume of $\mathrm{Zn}(\mathrm{II})$ ion metal solution and $\mathrm{m}$ is the mass of biosorbent. The characterization of biosorbent's functional groups was done by FTIR and surface morphology analysis by SEM-EDX.

\section{Results and Discussion}

\subsection{The Influence of $\mathbf{p H}$ on $\mathrm{Zn}$ (II) Absorption}

The initial $\mathrm{pH}$ of a solution is one of the important parameters to study metal biosorption process (Ting Fan et al, 2008). The results show that the maximum capacity of $\mathrm{Zn}$ (II) absorption obtained using Ca-alginate immobilized durian seed biosorbent is at $\mathrm{pH} 5$, with adsorption capacity of $2.01 \mathrm{mgg}-1$ (Figure 1). Previous study also obtained $\mathrm{pH} 5$ for durian seed (Lestari et al, 2015). 
Absorption capacity increases with the increase of solution's $\mathrm{pH}$ from 2 to 5 and decreases at pH 6 - 7. In low pH, competitions occur between ion $\mathrm{H}+$ and metal ion at absorption active side, with a big total of hydrogen ion limiting on metal ion absorption (Saikaew,2010., Sari dan Tuzen, 2009).

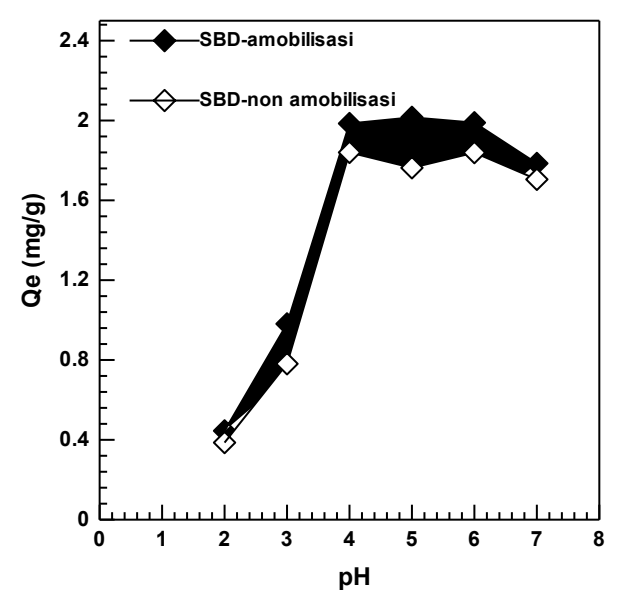

Figure 1 : The influence of $\mathrm{pH}$ on solution towards $\mathrm{Zn}(\mathrm{II})$ absorption capacity. (Initial concentration $=10 \mathrm{mgL}-1$, volume $=20 \mathrm{~mL}$, mass $=0.1 \mathrm{~g}$, contact time $=60$ minutes $)$

\subsection{The Influence of Contact Time on $\mathrm{Zn}($ II) Biosorption}

The contact time in $\mathrm{Zn}$ (II) biosorption learned in Ca-alginate immobilized durian seed biosrobent learned is between $15-120$ minutes. The maximum absorption capacity obtained at 120 minutes gave $\mathrm{Qe}$ value $=2.875 \mathrm{mg} / \mathrm{g}$. The results of $\mathrm{Zn}$ (II) absorption capacity can be seen in Figure 2.

Figure 2 shows that the increase of contact time length has resulted in the increase of $\mathrm{Zn}$ (II) absorption and finally constant at 75 minutes. Generally, metal ion reached equilibrium at 15 60 minutes and after that it becomes saturated (Adeel, 2013). In the initial condition, absorption took place fast as there is a big availability of active sides on the surface and it reached equilibrium afterwards. 


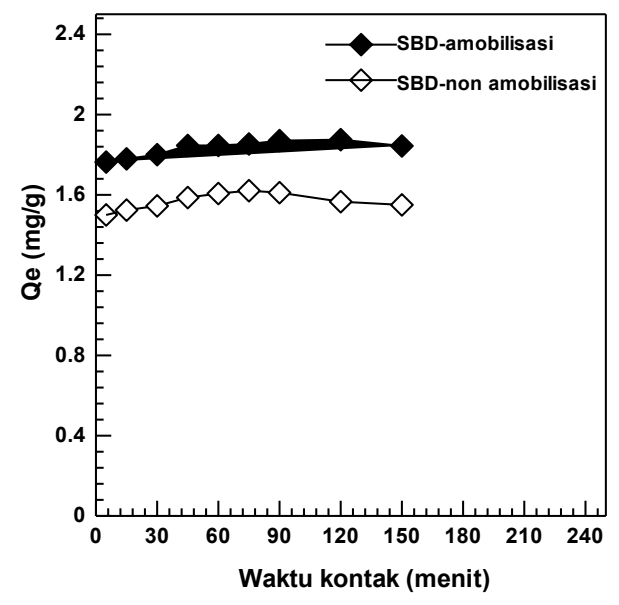

Figure 2. The influence of contact time on $\mathrm{Cd}$ absorption capacity, $\mathrm{pH} 4$ at non-immobilized and $\mathrm{pH}=5$ at SBD-immobilized, biosorbent mass $=0.1 \mathrm{~g}$, initial concentration $=10 \mathrm{mgL}-1$, stirring rate $=150 \mathrm{rpm}$.

\subsection{The Effect of Zn(II) Initial Concentration}

The influence of initial concentration of $\mathrm{Zn}(\mathrm{II})$ absorption at concentration range of $1-300$ $\mathrm{mg} / \mathrm{L} \mathrm{Zn(II)} \mathrm{can} \mathrm{be} \mathrm{seen} \mathrm{in} \mathrm{Figure} \mathrm{3.} \mathrm{The} \mathrm{higher} \mathrm{the} \mathrm{concentration} \mathrm{of} \mathrm{Zn}(\mathrm{II})$, the higher the absorption capacity. The maximum biosorption of $\mathrm{Zn}(\mathrm{II})$ ion obtained is at concetration of 250 $\mathrm{mg} / \mathrm{L}$ with $\mathrm{Qe}=25.05 \mathrm{mg} / \mathrm{g}$.

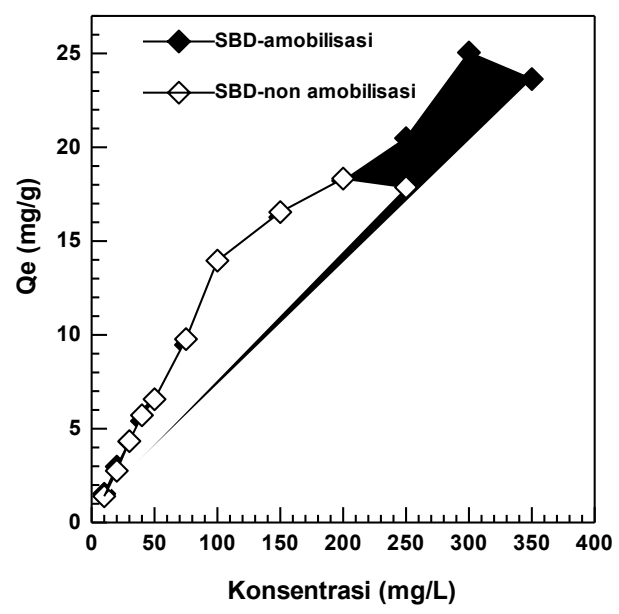

Figure 3 : The influence of solution concentration on $\mathrm{Zn}$ (II) biosorption by immobilized and non-immobilized biosorbent $(\mathrm{pH} \mathrm{Zn}$ solution $=5$, volume $=20 \mathrm{~mL}$, mass $=0.1 \mathrm{~g}$, contact time SBD - immobilized $=90$ minutes and SB-non immobilized $=45$ minutes $)$

The higher the concentration, the bigger the thrust force of metal ion to move to the surface of cell walls. Consequently, absorption capacity increases (Fun et al, 2008).

Table 1 : Metal ions biosorption capacity value by Ca-alginate immobilized biosorbent 


\begin{tabular}{|c|c|c|c|}
\hline $\begin{array}{l}\text { Alginate } \\
\text { Immobilized } \\
\text { Biomass }\end{array}$ & $\begin{array}{l}\text { Metal } \\
\text { ion }\end{array}$ & $\begin{array}{l}Q_{\max } \\
\left(\mathrm{mgg}^{-1}\right)\end{array}$ & Reference \\
\hline Micro alga & $\mathrm{Cu}^{2+}$ & 75.6 & Bayramoglu and Arica, 2009 \\
\hline Sqenedesmus & $\mathrm{Zn}^{2+}$ & 55.2 & \\
\hline quadricauda & $\mathrm{Ni}^{2+}$ & 30.4 & \\
\hline Mentha & $\mathrm{Cu}^{2+}$ & 104.48 & Hanif et al, 2009 \\
\hline arvensis & $\mathrm{Zn}^{2+}$ & 107.75 & \\
\hline \multirow[t]{2}{*}{ Penicilium sp } & $\mathrm{Cu}^{2+}$ & 17.2 & Misra, 2013 \\
\hline & $\mathrm{Zn}^{2+}$ & 19.1 & \\
\hline $\begin{array}{l}\text { Solanum } \\
\text { nigrum } \mathrm{L}\end{array}$ & $\mathrm{Zn}^{2+}$ & 144.72 & Indrasti and friends, 2009 \\
\hline Alga Chlorella & $\mathrm{Cu}^{2+}$ & 37.24 & Horvathova et al, 2009 \\
\hline kessleri & $\mathrm{Zn}^{2+}$ & 40.23 & \\
\hline
\end{tabular}

\subsection{Adsorption Isotherm}

The analysis to determine the absorption equilibrium between solid biosorbent and $\mathrm{Zn}$ (II) metal ion was done by Langmuir and Freundlich adsorption model isotherm.

\subsection{Langmuir Isotherm}

Langmuir model assumes one layer at adsorbents surface layer with limited total from the same part (Nawaz, et al., 2011). Langmuir equation can be written as follow:

$\frac{\mathrm{Ce}}{\mathrm{Qe}}=\frac{1}{\mathrm{Qmax} \cdot \mathrm{Kl}}+\frac{\mathrm{Ce}}{\mathrm{Qmax}}$

Where $\mathrm{Qe}=$ total metal ion absorbed at equilibrium per unit absorbent mass (mg/g). Qmax is maxium adsorption capacity for metal unit per adsorbent mass unit (mg.g). Ce is equilirbirum concentration of metal ion in the solution $(\mathrm{mg} / \mathrm{L})$ and $\mathrm{KL}$ shows Langmuir constant. Langmuir adsorption isotherm for $\mathrm{Zn}(\mathrm{II})$ ion at various temperatures can be seen in Figure 4. The plot of Ce value against $\mathrm{Ce} / \mathrm{Qe}$ values produce a straight line with 1/Qmax slope and 1/Qmax.KL intercept.
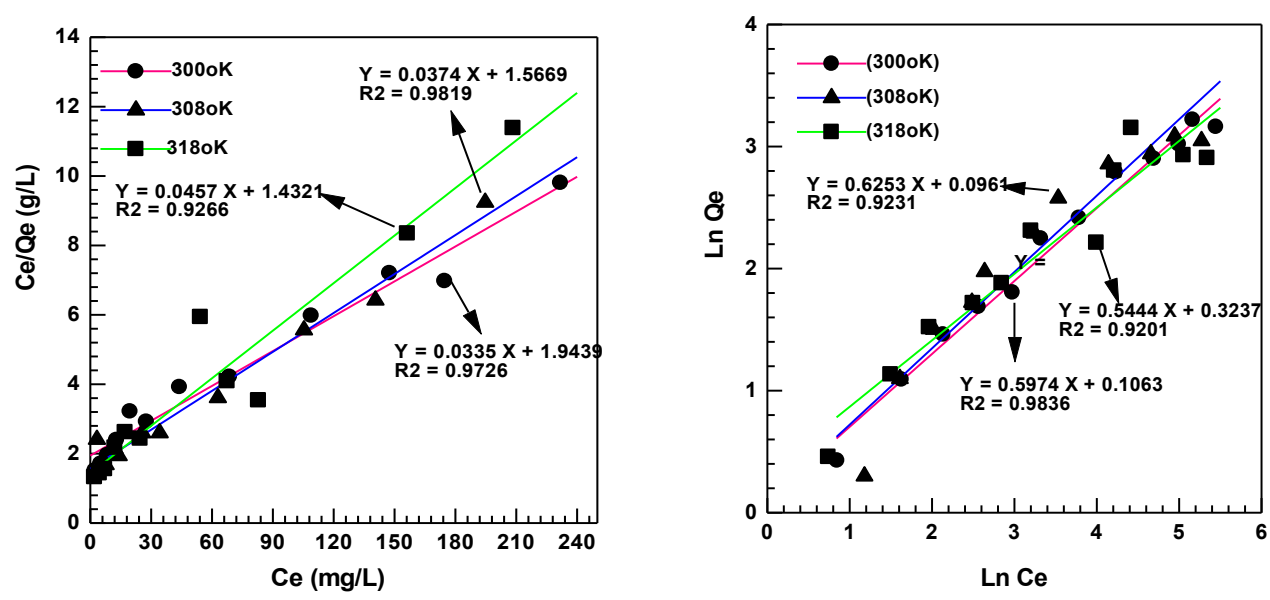
Figure 4A. Langmuir isotherm adsorption curve Figure 4B. Freundlich isotherm adsorption curve

Figure 4A and 4B show that temperature affects isotherm constant and maximum adsorption capacity. The correlation coefficient value (r) is more linier at $300 \mathrm{oK}$ with $\mathrm{r} 2=0.982$.

\subsection{Freundlich Isotherm}

Freundlich isotherms is empirical equation based on the adsorption at multilayers (heterogenous) surfaces (Kurniawan et al, 2014). Freundlich isotherm can be applied at multilayer adsorption. The linier equation of Freundlich isotherm can be written as: $\mathrm{Ln} \mathrm{Qe}=\mathrm{Ln}$ $\mathrm{KF}+1 / \mathrm{n}$ Ln Ce, where KF and $\mathrm{n}$ are Freundlich constant which can be determined by plotting Ln Qe against Ln Ce. The linier plot of Freundlich isotherm can be seen in Figure 4B.

\subsection{Biosorbent Characterization with FTIR}

FTIR spectra analysis done before and after metal ion biosorption is used to observe the functional groups in the biosorbent and the interaction with the metal ion after adsorption process. FTIR analysis in SBD-alginate immobilized biosorbent before and after $\mathrm{Zn}$ (II) biosorption can be seen in Figure 5. From the analysis, biosorbent with alginate immobilization has got several functional groups that can be seen at the stretched peak in wavelength 3424.20 cm-1 which is hydroxyl (-OH) or amine (-NH2). The band at $2925 \mathrm{~cm}-1$ is marken with $\mathrm{C}-\mathrm{H}$ stretching vibration and at $1636.91 \mathrm{~cm}-1$ is the stretching of bonds between carbonyl $\mathrm{C}=\mathrm{O}$ and amide. The peak at $1158.86 \mathrm{~cm}-1$ and $1023.65 \mathrm{~cm}-1$ are marked by the vibrations of stretching alcohol.

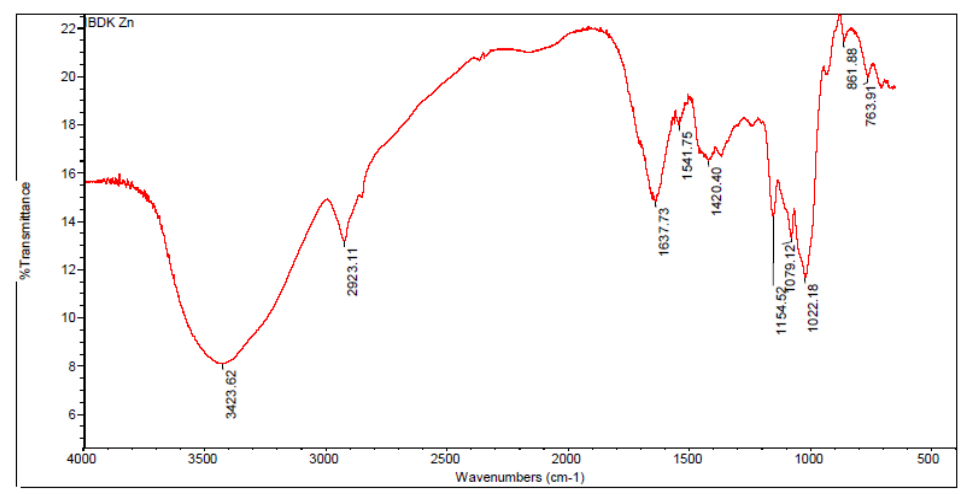

Figure 5 : FTIR Spectra for Ca-alginate immobilized durian seed biosorbent before absorption

The shift of wavelength took place after $\mathrm{Zn}$ (II) metal ion absorption which can be seen in Figure 5b. The spectra shows the shifts at $3423.20 \mathrm{~cm}-1$ and $3423.62 \mathrm{~cm}-1$ which care marked by -OH or -NH2 functional groups intensity with adsorbates. Next, the peak at $2925 \mathrm{~cm}-1$ to $2923.11 \mathrm{~m}-$ 1 is marked by stretching vibration of $\mathrm{C}-\mathrm{H}$. Then the peak at $1636.91 \mathrm{~cm}-1$ to $1637.73 \mathrm{~cm}-1$ is marked in stretching vibration of carbonyl $\mathrm{C}=\mathrm{O}$ group. From biosorption FTIR spectra of metal ion $\mathrm{Zn}(\mathrm{II})$ biosorption took place involved carboxyl, carbonyl, hydroxyl and amine 
functional groups at the surfaces of biomass. The same functional groups were also obtained at $\mathrm{Cu}$ (II) biosorption in Trametes versicolor biomass (Subbaiah et al, 2011).

\section{Conclusion}

In this study, Ca-alginate immobilized durian seed (Durio zibethinus) biosorbent has been used as one of the potential biosorbents to absorb $\mathrm{Zn}(\mathrm{II})$ in a solution. The biosorption characteristic learned are by various parameters like $\mathrm{pH}$, contact time, solution concertation and temperature. The optimum conditions are at pH 5 with 75 minutes contact time, initial concentration of $250-$ $300 \mathrm{mgL}-1$ in room temperature. The research data was analyzed by Langmuir and Freundlich isotherm. Equilibrium data follows more of Langmuir adsorption model with $\mathrm{r} 2=0.9726$. The maximum biosorption capacity obtained was $\mathrm{Qe}=25.05 \mathrm{mgg}-1$.

\section{References}

[1] Abbas S.H., I.M. Ismail, T.M.Mostafa, A.H.Sulaymon, (2014), Biosorption Of Heavy Metals: A Review, J. Of Chemical Science and Technology, Vol 3 Iss. 4, pp. 74-102.

[2] Adeel H. M., B.Parveen, N. Rasool, M. Riaz, K.G.Ali, Y. Gull, M. Noreen, M.Asghar., 2013, Biosorption of Copper (II) From Aqueous Solution by Ocimum bacilium Seed biomass, IJCBS, 4(2013) : 38-45.

[3] Aksu, Z., G. E. Retli and T. Kutsal. 1998.1A comparative study of copper(II) biosorption on Ca-alginate, agarose and immobilized C. vulgaris in a packed-bed column. Process Biochemistry. Vol. 33. No 4 : 393-400.

[4] Bayramoglu, G., I. Tuzun., G. Celik., M. Yilmaz and M.Y. Arica. 2006. Biosorption or mercury(II), cadmium(II) and lead(II) ions from aqueous solution system by microalgae Chlamydomonas reinhardtii immobilized in alginate beads, Int.J. Miner.Process. 81. $35-43$.

[5] Coelho, T. C., Laus, R., Mangrich, A. S., de Favere, V. T., \& Laranjeira, C. M. 2007. Effect of heparin coating on epichlorohydrin cross-linked chitosan microspheres on the adsorption of copper (II) ions. Reactive and Functional Polymers, 67, pp. 468-475.

[6] Das, N., R.Vimala, and P. Karthika. 2007, Biosorption of heavy metal- An overview, Indian J. Of Biotechnology, Vol 7, pp. 159-169.

[7] Fan, T., Y. Liu., B. Feng., G. Zeng., C.Yang and M. Zhou. 2008. Biosorption of Cadmium(II), Zinc(II) and Lead(II) by Penicillium simplicissimum: Isotherms, kinetics, and thermodynamics. J. Hazardous Materials.160 : 655-661.

[8] Gadd, G. M. 1993. Interactions of fungi with toxic metals. Phytologist, 124, pp. 25-60.

[9] Hanif, A., H.N. Bhattiand M.A. Hanif. 2009. Removal and recovery of $\mathrm{Cu}(\mathrm{II})$ and $\mathrm{Zn}(\mathrm{II})$ using immobilized Menthaarvensis distillation waste biomass. Ecological Engineering.35 : 1427-1434. Horvathova, H., D. Ivanova., J. Kadukova., J. Kavulicova and M. Stovko.

[10] 2010.Biosortion of $\mathrm{Cu} 2+$ and $\mathrm{Zn} 2+$ by immobilized biosorbents : Study of The Biosorbent Stability and capacity.Mineralia Slovaca.Vol42 : 291-294. 
[11] Indrasti, N.S., M.A. Subroto dan G.G Gunawan. 2010. Adsorpsi Logam Berat Seng (Zn) Menggunakan Akar Rambut Solanumnigrum L Galur A4 Kering Terimmobilisasi Dalam Na-alginat. J. Tek. Ind. Pert. Vol 15(1) : 1-9.

[12] Kacar Y., Arpa C., Tan S, , Denizli A., Genc, O, Arıca Y.M., 2002, Biosorption of $\mathrm{Hg}(\mathrm{II})$ and $\mathrm{Cd}(\mathrm{II})$ from aqueous solutions: comparison of biosorptive capacity of alginate and immobilized live and heat inactivated Phanerochaete chrysosporium. Process Biochemistry 37 pp. $601-610$.

[13] Kurniawan, M.I., Z. Abdullah., A. Rahmadani., R. Zein., E. Munaf. 2014. Isotherm and Kinetic modeling of $\mathrm{Pb}(\mathrm{II})$ and $\mathrm{Cu}(\mathrm{II})$ Uptake by Annonamuricata $\mathrm{L}$ seed. Asian Journal.Chem. 26 (12) : 3588-3594.

[14] Mahamadi, C and P. Zambara. 2012. Adsorption of Cu(II) From Aquatic System Using alginate-Immobilized Water Hyacinth Beads. European Journal of Scientific Research.Vol 71. No $4: 581-589$.

[15] Misra, S.P. 2013. Adsorption of $\mathrm{Cu}$ and $\mathrm{Zn}$ on Calcium alginate immobilized Penicillium sp. Indian Journal Of Chemical Technology. Vol $20: 21-25$.

[16] Nawas, H., Bhatti., R. Khadim and M.A. Hanif. 2011. Biosorption of $\mathrm{Pb}$ (II) and $\mathrm{Co}$ (II) On Red Rose Waste Biomass. Iran. J.Chemical.Chemistry. Eng.Vol 30 : No 4.

[17] Osman, H.E., R.K. Badwyand H.F. Ahmad. 2010. Usage of Agricultural By products in The Removal of Some Heavy metal from Industrial wastewater. Journal of Phytology. 2(3) : 51-62.

[18] Pehlivan E., Altun T, Parlayici S., 2012, Modified barley straw as a potential biosorbent for removal of copper ions from aqueous solution, Food Chemistry 135 , pp. 22292234

[19] Saikaew, W and P. Kaewsam. 2009. Durian Peel AsBiosorbent for Removal Of Cadmium Ions from Aqueous Solution. J.Environ.Res. 32 (1) : 17-30.

[20] Sari, A dan M.Tuzen. 2009. Kinetic and equilibrium studies of biosorption of $\mathrm{Pb}$ (II) and $\mathrm{Cd}(\mathrm{II})$ from aqueous solution by macrofungus (Amanita rubescens) biomass. $\mathrm{J}$ of Hazard Materials. 164 : 1004-1011. 